\title{
PENINGKATAN KEMAMPUAN MENGARANG CERPEN MELALUI PEMBELAJARAN KONTEKSTUAL DENGAN INSPIRATOR FILM DOKUMENTER PADA SISWA KELAS VIII B SMP PGRI 7 DENPASAR TAHUN PELAJARAN 2015/2016
}

\author{
I Wayan Agus Heri, I Gusti Ayu Putu Tuti Indrawati \\ Program Studi Pendidikan Bahasa Indonesia, Fakultas Keguruan dan Ilmu Pendidikan \\ Universitas Mahasaraswati Denpasar
}

\begin{abstract}
ABSTRAK
Penelitian ini merupakan penelitian tindakan kelas. itu bertujuan untuk meningkatkan kemampuan siswa dalam mengarang cerita pendek dengan menerapkan pembelajaran kontekstual melalui inspirasi film dokumenter. penelitian ini dilakukan dikelas VIIIB SMP PGRI 7 Denpasar, pada tahun akademik 2015/2016. Data dikumpulkan melaluites, observasi, dan wawancara. Analisis data yang digunakan dalam penelitian ini adalah deskriptif kuantitatif. hasil menunjukkan bahwa ada peningkatan disetiap siklus. pada prates, skor adalah 4,78, meningkat masing-masing menjadi 5,60 pada siklus I, 6,66 pada siklus II, dan 8,30 pada siklus III.
\end{abstract}

Kata Kunci : mengarang cerpen, inspiratorfilm dokumenter, kontekstual

ABSTRACT

This study is a classroom action research. it aimed to improve the student ability in trump up the short story by implementing contextual learning through inspiration documentary. the study was conducted at class VIII B SMP PGRI 7 Denpasar, in the academic year 2015/2016. data was collected through test, observation, and interview. The data analysis used in this research is quantitative descriptive. the results shown that there was improvement in every cycle. on pre tes, the score was 4,78, it increased respectively into 5,60 in cycle I, 6,66 in cycle II, and 8,30 in cycle III.

Key Words : trump up the short story, inspiration documentary, contextual

\section{PENDAHULUAN}

Ada empat aspek keterampilan berbahasa yang harus diperhatikan yaitu menyimak, berbicara, membaca, dan menulis. Keempat keterampilan tersebut saling terkait satu sama lain. Setiap keterampilan itu dapat dipelajari dan dilatih melalui pembiasaan. Keberadaan keterampilanmenulis dalam pembelajaran bahasa di sekolah mutlak diperlukan, khususnya dalam pembelajaran mengarang. Melalui kegiatan mengarang diharapkan siswa dapat menuangkan ide-ide atau gagasan baik yang bersifat ilmiah maupun imajinatif. Oleh karena itu, sekolah tempat mengenyam pendidikan diharapkan dapat memberikan pembelajaran mengarang dengan baik melalui metode yang tepat sehingga potensi dan daya kreatifitas siswa dapat tersalurkan. Pembelajaran sastra (cerpen) sebagai salah satu pelajaran di sekolah menengah juga memiliki keterkaitan dengan pembelajaran mengarang. Sebagai salah satu bagian dari mata pelajaran sastra, sastra menjadi sesuatu yang sulit untuk dipelajari siswa. Seperti yang dikatakan 
Superhar (2006 : 97) bahwa pelajaran sastra, dalam pandangan orang dewasa termasuk pihak sekolah ternyata bukanlah pelajaran yang menarik untuk diberikan dengan sungguh-sungguh dan serius kepada anakanak di sekolah. Pelajaran yang diberikan kepada siswa adalah pelajaran ilmu pengetahuan alam dan sosial, serta bahasa Inggris sebagai pelajaran yang sangat penting penguasaannya bagi masa depan anak.

Berdasarkan hasil wawancara dengan guru mata pelajaran bahasa Indonesia di kelas VIII B SMP PGRI 7 Denpasar, keterampilan mengarang cerpen telah diajarkan tetapi belum mencapai ketuntasan karena dipengaruhi oleh beberapa hambatan diantaranya, siswa tidak mempunyai bakat untuk mengarang, siswa kesulitan menentukan kata pertama dalam mengarang, siswa jarang berlatih mengarang, dan selain itu guru kurang terampil dalam mengajarkan mengarang. Menurut hasil observasi nilai rata-rata kelas untuk mata pelajaran bahasa Indonesia siswa kelas VIII B SMP PGRI 7 Denpasar dalam tes pra-semester yaitu 65 . Ini menunjukan bahwa prestasi belajar siswa tergolong masih rendah karena nilai rata-rata (KKM) yang ditetapkan yakni 75 . Hal ini diakibatkan belum efektifnya pembelajaran yang dilaksanakan di kelas. Oleh karena itu dapat diambil kesimpulan bahwa peran guru amat dominan dalam proses pembelajaran. Siswa kurang aktif dan sering kali metode ceramah menimbulkan kebosanan bagi siswa dalam pembelajaran mengarang cerpen sehingga karya yang dihasilkan siswa kurang maksimal. Cerpen yang dibuatnya kurang menarik karena bahasa yang digunakan monoton dan pengembangan ide atau gagasan kurang bervariasi.

Guru sebagai penyampai materi kepada siswa harus dapat menyampaikan materi yang akan dibahas dengan metode dan media yang tepat dan menarik. Hal tersebut akan berdampak pada keberhasilan siswa agar menjadi lebih aktif, kreatif dan inovatif. Dari uraian di atas, maka salah satu pendekatan pembelajaran bahasa Indonesia yang dirasa sesuai digunakan adalah pendekatan pembelajaran kontekstual dengan inspirator film dokumenter. Pendekatan pembelajaran kontekstual merupakan suatu proses pendidikan yang bertujuan memotivasi siswa untuk memahami makna materi pelajaran yang dipelajarinya dengan mengkaitkan materi tersebut dengan konteks kehidupan mereka sehari-hari (konteks pribadi, sosial, dan kultural) sehingga siswa memiliki pengetahuan/keterampilan yang secara fleksibel dapat diterapkan (ditransfer) dari satu permasalahan/konteks ke permasalahan/konteks lainnya, melalui inspirator film dokumenter diharapkan dapat merangsang daya imajinasi siswa dalam menghasilkan karya sastra berupa cerpen.

Berdasarkan uraian di atas, maka penulis berkeinginan meningkatkan kemampuan mengarang cerpen dengan melakukan penelitian dalam bentuk penelitian tindakan kelas dengan judul "Peningkatan Kemampuan Mengarang Cerpen Melalui Pembelajaran Kontekstual dengan Inspirator Film Dokumenter pada Siswa Kelas VIII B SMP PGRI 7 Denpasar Tahun Pelajaran 2015/2016". Berdasarkan pemaparan tersebut, maka permasalahan yang dibahas dalam penelitian ini adalah (1) 
Apakah metode pembelajaran kontekstual dengan inspirator film dokumenter dapat meningkatkan kemampuan mengarang cerpen pada siswa kelas VIII B SMP PGRI 7 Denpasar tahun pelajaran 2015/2016? (2) Bagaimanakah langkah-langkah model pembelajaran kontekstual dengan inspirator film dokumenter dalam pembelajaran mengarang cerpen pada siswa kelas VIII B SMP PGRI 7 Denpasar tahun pelajaran 2015/2016?. Adapun ruang lingkup penelitian ini terbatas hanya pada peningkatan kemampuan mengarang cerpen melalui pembelajaran kontekstual dengan inspirator film dokumenter pada siswa kelas VIII B SMP PGRI 7 Denpasar Tahun Pelajaran 2015/2016. Tujuan umum penelitian ini adalah dapat memberikan sumbangan pemikiran dan meningkatkan wawasan dalam mengarang cerpen melalui model pembelajaran kontekstual dengan inspirator film dokumenter dalam upaya membina serta mengembangan bahasa dan sastra Indonesia. Tujuan khusus penelitian ini yaitu (1) untuk mendapatkan data yang pasti tentang model pembelajaran kontekstual dengan inspirator film dokumenter dapat meningkatkan keterampilan mengarang cerpen pada siswa kelas VIII B SMP PGRI 7 Denpasar tahun pelajaran 2015/2016, (2) Untuk mengetahui langkah-langkah model pembelajaran kontekstual dengan inspirator film dokumenter dapat meningkatkan keterampilan mengarang cerpen pada siswa kelas VIII B SMP PGRI 7 Denpasar tahun pelajaran 2015/2016.

\section{METODE PENELITIAN}

Jenis penelitian yang digunakan yaitu penelitian tindakan kelas (PTK). Penelitian Tindakan Kelas yaitu suatu kajian mengenai situasi sosial yang berguna untuk memperbaiki kualitas tindakan dari situasi sosial tersebut yang meliputi situasi sosial kelas, praktik pendidikan dan kegiatan belajar mengajar di kelas. Tujuan penelitian tindakan kelas adalah pengembangan kemampuan keterampilan guru dalam menghadapi permasalahan aktual pembelajaran di kelasnya atau di sekolahnya sendiri sehingga dapat meningkatkan hasil belajar siswa yang baik.

Subjek penelitian dalam penelitian tindakan ini adalah siswa kelas VIII B SMP PGRI 7 Denpasar tahun pelajaran 2015/2016yang terdiri dari 17 Orang siswa laki-laki dan 16 siswi perempuan.Objek penelitian ini adalah peningkatan kemampuan mengarang cerpen melalui pembelajaran kontekstual dengan inspirator film dokumenter pada siswa kelas VIII B SMP PGRI 7 Denpasar. Tempat penelitian dalam penelitian tindakan ini yaitu SMP PGRI 7 Denpasar.

Rancangan penelitian di rancang sampai siklus ke-N. Pelaksanaan siklus dapat di katakan berhasil ketika nilai siswa sudah mencapai $75 . \quad$ Posedur penelitianmerupakan suatu rangkaian tindakan penelitian yang terdiri dari empat tahap yaitu perencanaan, tindakan, pengamatan dan refleksi, KurtLewin dalam Kunandar (2008:42).Refleksi awal dilakukan dengan observasi dengan tujuan untuk mengamati siswa dan melakukan evaluasi untuk mengetahui kelemahan kelemahan yang dialami siswa dalam 
mengarang cerpen dan melakukan tes awal guna mengetahui kemampuan dasar yang dimiliki oleh siswa. Tes awal ini digunakan sebagai titik tolak untuk menentukan kemajuan yang dicapai pada penelitian.

Dalam penelitian ini peneliti menggunakan metode tes untuk mengumpulkan data. metode tes adalah cara memperoleh data yang terbentuk suatu tugas yang harus dikerjakan oleh seseorang atau kelompok orang yang dites dan dari tes tersebut dapat mengahasilkan suatu skor, dan selanjutnya skor tersebut dibandingkan dengan kriteria atau standar tertentu (silvester, 2010:41). Bentuk tes yang digunakan dalam penelitian ini berupa tes membuat cerpen. Jumlah aspek yang dinilai adalah 5 aspek dan setiap aspek diberi skor maksimal 20.Adapun aspek yang dinilai yaitu keunikan alur cerita, tokoh, latar,keterkaitan isi cerpen dengan tema, nilai positif yang disampaikan/amanat.Metode wawancara adalah cara menghimpun bahan keterangan yang dilakukan dengan tanya jawabsecara lisan, secara sepihak, berhadapan muka, dan dengan arah serta tujuan yang telah ditetapkan. Metode observasi merupakan suatu kegiatan yang memperhatikansebuah objek denganmenggunakanseluruhalat indera (Arikunto,1989:146).Instrument yang digunakan dalam penelitian ini adalah tes tulis (esai).

Analisis data yang digunakan dalam penelitian ini adalah analisis data deskriptif kuantitatif. Untuk lebih mudah menentukan skor atau nilai dapat dirumuskan sebagai berikut :

$$
\mathrm{M}=\frac{\sum f x}{\mathrm{~N}}
$$

\section{HASIL PENELITIAN DAN PEMBAHASAN}

Dari pelaksanaan penelitian tindakan kelas (PTK) ini, telah diperoleh data yang diperlukan untuk dievaluasi. Data yang diperoleh adalah berupa hasil observasi terhadap guru dan siswa selama pelaksanaan penelitian tindakan kelas, dan data hasil tes peningkatan kemampuan mengarang cerpen.

Observasi terhadap kegiatan pembelajaran dilakukan oleh peneliti. Dari observasi inilah dapat diketahui permasalahan siswa dalam mengikuti pelajaran bahasa Indonesia, khususnya dalam mengarang cerpen. Adapun hasil observasi yang telah dilakukan adalah: (1) pembelajaran yang diterapkan oleh guru bersifat konvensional, (2) siswa hanya mengandalkan catatan dari guru dan berpedoman pada LKS, (3) siswa kurang termotivasi, (4) siswa takut bertanya kepada guru mengenai hal-hal yang kurang jelas, (5) siswa kurang mengerti bagaimana cara mengarang cerpen.

Tahap awal yang dilakukan oleh peneliti pada tanggal 5 Februari 2016, peneliti memberikan tes terlebih dahulu untuk mengetahui kemampuan awal siswa dalam mengarang cerpen dengan tema bebas. Dari hasil tes awal tersebut dapat diketahui bahwa skor standar siswa adalah 158 dengan nilai rata-rata 4,78 dengan kategori kurang.

Siklus I dilaksanakan pada hari Jumat, Tanggal 6 Februari 2016. Pada siklus ini penulis menerapkan pembelajaran 
kontekstual dalam mengarang cerpen dengan inspirator film dokumenter tahap pertama. Dari hasil tes siklus I dapat diketahui bahwa skor standar yang diperoleh siswa adalah sejumlah 185 dengan nilai ratarata 5,60 dengan kategori hampir cukup. Hasil tersebut belum memenuhi target yang ditentukan, maka akan dilakukan perbaikan pada siklus II.

Pada tahap ini, pembelajaran siklus II dilaksanakan pada hari Senin, Tanggal 9 Februari 2016. Pada siklus II peneliti memberikan pengulangan materi-materi yang belum dipahami dan melanjutkan skenario pembelajaran yang sudah dipersiapkan. Dari hasil tes siklus IIdapat diketahui bahwa skor standaryang diperoleh yaitu sejumlah 220 dengan nilai rata-rata 6,66 dengan kategori cukup.Hasil tes tersebut belum memenuhi target yang ditentukan dan akan dilanjutkan pada siklus III untuk memperoleh hasil yang lebih baik.

Pelaksanaan pembelajaran siklus III dilaksanakan pada hari Kamis, tanggal 12
Februari 2016. Pelaksanaan siklusIIIdilakukan untuk menindaklanjuti kendala pada siklus II. Untuk mendapatkan hasil yang diinginkan, maka peneliti terus memberikan pengulangan materiuntuk dapat meningkatkan minat siswa dalam mengarang cerpen melalui pembelajaran kontekstual dengan inspirator film dokumenter.Hasil penelitian pada siklus III dalam mengarang cerpen dapat dikatakanmengalami peningkatan sesuai denganyang diharapkan. Banyak siswa yang mendapatkan nilai tinggi dengan kriteria baik sekali dan baik. Skor standar yang diperoleh pada siklus ini yaitu sejumlah 274 dengan nilai rata-rata 8,30 dengankategori baik.Denganpencapaian nilai rata-rata 8,30 padasiklus III, makapeneliti tidak perlulagimelanjutkanpelaksanaan pembelajaran pada siklus berikutnyakarena sudah memenuhitarget yang telahditentukanyaitu 75 .

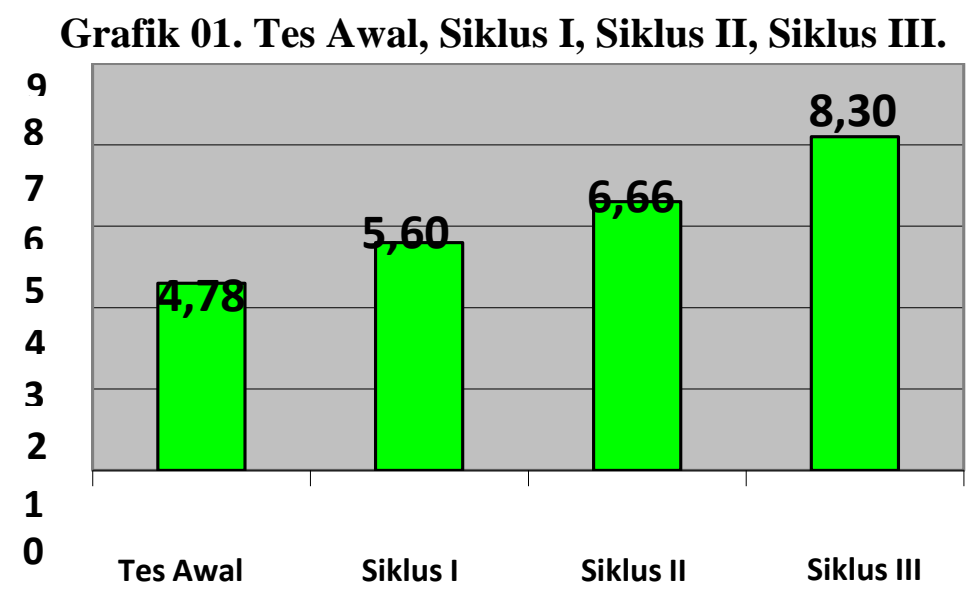

\section{PENUTUP}

\section{Simpulan}

Berdasarkan hasil penelitian serta pembahasan yang telah dipaparkan, peneliti dapat menarik simpulan, bahwa Model pembelajaran kontekstual dengan inspirator film dokumenter dapat meningkatkan kemampuan mengarang cerpen pada siswa 
kelas VIII B SMP PGRI 7 Denpasar Tahun Pelajaran 2015/2016. ini dapat dilihat dari peningkatan nilai rata-rata yang diperoleh siswa pada tes awal (pra test) jumlah ratarata 4,78 dengan kategori kurang, pada siklus I mengalami peningkatan nilai ratarata 5,60 dengan kategori hampir cukup, siklus II mengalami peningkatan nilai ratarata siswa menjadi 6,66 dengan kategori cukup, dan pada siklus III juga mengalami peningkatan nilai rata-rata siswa menjadi 8,30 dengan kategori baik.

\section{Saran}

Hasil penelitian telah membuktikan secara objektif bahwa kemampuan siswa dalam mengarang cerpen dapat ditingkatkan. Oleh karena itu data tersebut kiranya dapat diberikan saran-saran sebagai berikut :

1. Pembelajaran kontesktual dapat diterapkan sebagai salah satu upaya untuk meningkatkan hasil belajar siswa pada pembelajaran mengarang cerpen.

2. Siswa perlu melatih kemampuan dalam mengarang cerpen.

3. Kepada guru bahasa Indonesia hendaknya memberi motivasi kepada siswa agar tidak mengabaikan pembelajaran sastra khususnya dalam mengarang cerpen.

4. Disarankan bagi peneliti berikutnya untuk dapat mengembangkan penelitian tentang metode pembelajaran, sebab pada dasarnya terdapat beberapa metode pembelajaran yang lain yang dapat digunakan untuk meningkatkan motivasi belajar siswa.

\section{DAFTAR PUSTAKA}

Arikunto. (1989). Prosedur Penelitian. Jakarta : Bina Aksara.

Kunandar. (2008).Langkah Mudah PenelitianTindakan Kelas SebagaiPengembangan ProfesiGuru. Jakarta : Raja Grafindo Persada.

Silvester.(2010).Metodologi PenelitianPendidikan Suatu Pengantar. Singaraja : Fakultas Ilmu Pendidikan UNDIKSHA.

Superhar. (2006).Pembelajaran Sastra. Surabaya 